\title{
Role of Intestinal Ultrasound in the Evaluation of Postsurgical Recurrence in Crohn's Disease: Correlation with Endoscopic Findings
}

\author{
Cláudia Patricia Macedo ${ }^{a}$ Mara Sarmento Costa ${ }^{a}$ Elisa Gravito-Soares ${ }^{a}$ b \\ Marta Gravito-Soares ${ }^{a, b}$ Ana Margarida Ferreira ${ }^{a}$ Francisco Portela ${ }^{a}$ b \\ Pedro Figueiredo ${ }^{\mathrm{a}, \mathrm{b}}$ \\ ${ }^{a}$ Gastroenterology Department, Centro Hospitalar e Universitário de Coimbra, Coimbra, Portugal; b University of \\ Coimbra, Faculty of Medicine, Coimbra, Portugal
}

\section{Keywords}

Intestinal ultrasound · Postsurgical recurrence $\cdot$ Crohn disease

\section{Abstract}

Introduction: Endoscopy remains the exam of choice in the evaluation of activity in Crohn's disease (CD) after surgery (ACD-AS). However, intestinal ultrasound (IUS) may represent a noninvasive alternative. The objective of this study is to determine the diagnostic accuracy of this modality compared to endoscopy. Material and Methods: This is a crosssectional study, comprising a period of 14 months, carried out in patients with established CD and ileocecal resection due to the disease. IUS (HI-VISION Avius ${ }^{\circledR}$, Tokyo, Japan) was performed with linear probe B-mode/Doppler prior to ileocolonoscopy. IUS and ileocolonoscopy were performed on the same day by 2 specialists in Gastroenterology dedicated to ultrasound and inflammatory bowel disease, in a doubleblind mode. Collected demographic and clinical data (Harvey-Bradshaw Index [HBI]; remission $\leq 4)$, serological/fecal inflammatory parameters (leukocytes [4-10 $\times 10^{9}$ cells/L], Creactive protein $[\leq 0.5 \mathrm{mg} / \mathrm{dL}]$, and fecal calprotectin $[<50$ $\mathrm{mg} / \mathrm{kg}]$ ), endoscopy (Rutgeerts score: remission $<\mathrm{i} 2$ ), and ultrasound (intestinal wall thickening $[\leq 3 \mathrm{~mm}]$ and digestive

karger@karger.com www.karger.com/pjg

Karger ${ }^{\prime \prime} \div$

GOPEN ACCESS
(C) 2021 Sociedade Portuguesa de Gastrenterologia Published by S. Karger AG, Basel

This is an Open Access article licensed under the Creative Commons Attribution-NonCommercial-4.0 International License (CC BY-NC) (http://www.karger.com/Services/OpenAccessLicense), applicable to the online version of the article only. Usage and distribution for commercial purposes requires written permission. wall vascularization using the semiquantitative score of Limberg [absent $=0$, sparse $=1$, moderate $=2$, and marked $=3$ ]). Results: Thirty-nine patients (female: $64.1 \%$, mean age: 43.5 \pm 15.3 years) were included. The median post-surgery follow-up was 9 years (IQR 3-12). The Montreal classification was as follows: L1, $61.5 \%(n=24) ; \mathrm{L} 3,38.5 \%(n=15) ; \mathrm{B} 1$ and $\mathrm{B} 2,28.2 \%(n=11)$; and B3, 43.6\% ( $n=17)$. Most patients were in clinical remission $(87.2 \% ; n=34)$, with a mean HBI of $2.1 \pm$ 2.2. Twenty-two patients (56.4\%) had normal inflammatory markers. IUS (intestinal wall thickening $>3 \mathrm{~mm}$ and/or Limberg score $>1)$ was abnormal in $61.5 \%(n=24)$ of the cases. Endoscopic remission (Rutgeerts score $<\mathrm{i} 2)$ in $53.8 \%(n=21)$ of the cases. Compared to endoscopy, IUS (area under the receiver operating characteristic curve [AUROC] $=0.75, p=$ 0.007 ) showed a diagnostic accuracy superior to that of inflammatory parameters (AUROC $=0.66, p=0.083$ ) and clinical parameters $(A \cup R O C=0.64, p=0.139)$. IUS showed a moderate concordance with endoscopy $(\kappa=0.5, p=0.001)$, which was higher than that with inflammatory parameters $(\mathrm{k}=$ $0.33, p=0.041)$ or clinical parameters $(k=0.29, p=0.01)$. Conclusions: Ultrasound evaluation of the digestive wall is a noninvasive technique that shows a good diagnostic accuracy and a moderate concordance with endoscopy, being superior to clinical and serological/fecal inflammatory parameters. (c) 2021 Sociedade Portuguesa de Gastrenterologia Published by S. Karger AG, Basel
Correspondence to:

Cláudia Patricia Macedo, claudia.macedo.07@hotmail.com

Mara Sarmento Costa, marajoaodacosta@ hotmail.com 
Papel da ecografia da parede digestiva na avaliação da recorrência pós-cirúrgica na Doença de Crohn: correlação com os achados endoscópicos

\section{Palavras Chave}

Ecografia da parede digestiva · Recorrência pós-cirúrgica . Doença de Crohn

\section{Resumo}

Introdução: A endoscopia permanece o exame de eleição na avaliação da atividade da Doença de Crohn (DC) póscirurgia ( $A D C-P C)$. No entanto, a ecografia dirigida à parede digestiva (Eco-PD) pode representar uma alternativa não-invasiva. $\mathrm{O}$ objetivo do trabalho é determinar a acurácia diagnóstica e concordância desta modalidade comparativamente à endoscopia. Materiais e métodos: Estudo transversal, compreendendo um período de 14 meses, efetuado a doentes com DC estabelecida e resseção ileocecal pela doença. Realizada Eco-PD (HI-VISION Avius ${ }^{\circledR}$, Tokyo, Japan) com sonda linear em modo-B/ Doppler previamente à ileocolonoscopia. A Eco-PD e ileocolonoscopia foram realizadas no mesmo dia por 2 especialistas dedicados a ecografia e doença inflamatória intestinal, de forma duplamente cega. Recolhidos dados demográficos, clínicos (índice Harvey-Bradshaw [HBl; remissão: $\leq 4]$ ), parâmetros inflamatórios serológicos/fecais (leucócitos $\left[4<\mathrm{N}<10 \times 10^{9}\right.$ células/L], proteína $C$ reativa $[\leq 0,5 \mathrm{mg} / \mathrm{dL}]$, calprotectina fecal $[\mathrm{N}<50 \mathrm{mg} / \mathrm{kg}]$ ), endoscópicos (score Rutgeerts: remissão < i2) e ecográficos (espessamento [ $\mathrm{N} \leq 3 \mathrm{~mm}$ ] e vascularização da parede digestiva pelo score semi-quantitativo de Limberg [ausente $=0$; escassa $=1$; moderada $=2 ;$ marcada $=3]$ ). Resultados: Incluídos 39 doentes (sexo feminino: 64,1\%, idade média: $43,5 \pm 15,3$ anos). Seguimento mediano pós-cirurgia de 9 anos (IQR 9). Classificação Montreal: L1 61,5\% $(n=24)$, L3 $38,5 \%(n=15)$, B1 e B2 $28,2 \%(n=11)$ e B3 43,6\% ( $n=17)$. A maioria estava em remissão clínica $(87,2 \% ; n=34)$ com HBI médio de $2,1 \pm 2,2$. Vinte e dois doentes $(56,4 \%)$ tinham marcadores inflamatórios dentro de parâmetros normais. A Eco-PD (espessamento parede intestinal $>3 \mathrm{~mm}$ e/ou Limberg $>1)$ foi anormal em 61,5\% ( $n=24)$. Remissão endoscópica (Rutgeerts $<\mathrm{i} 2)$ em $53,8 \%(n=21)$. Comparativamente à endoscopia, a Eco-PD (AUROC 0,$75 ; p=$ $0,007)$ mostrou acuidade diagnóstica superior aos parâmetros inflamatórios (AUROC 0,66; $p=0,083$ ) e clínica (AUROC 0,$64 ; p=0,139$ ). A ecografia mostrou uma moderada concordância com a endoscopia ( $\mathrm{K}=0,5 ; p=0,001)$, superior aos parâmetros inflamatórios $(\kappa=0,33, p=0,041)$

Role of IUS in CD's Postsurgical

Recurrence ou clínica ( $\kappa=0,29, p=0,01$ ). Conclusões: $\mathrm{A}$ avaliação ecográfica da parede digestiva é uma técnica não invasiva que mostrou uma boa acuidade diagnóstica e uma concordância moderada com a endoscopia, superior à clínica e parâmetros inflamatórios serológicos/fecais.

(C) 2021 Sociedade Portuguesa de Gastrenterologia Publicado por S. Karger AG, Basel

\section{Introduction}

Therapeutic management of Crohn's disease (CD) is challenging, although novel immunomodulators and biological therapies are available and rapidly evolving. CD is a chronic inflammatory bowel disease (IBD) and frequently has a relapsing and remitting course. More than $80 \%$ of CD patients require surgery within 10 years of diagnosis [1]. After a first resection of the terminal ileum in CD, up to $80 \%$ of patients have endoscopic evidence of recurrence within 12 months [2].

Thirty years ago, Rutgeerts et al. [2] showed us how complex the postoperative course of CD can be and, later, the Rutgeerts score was proposed as a grading system according to endoscopic findings after surgery. Endoscopic changes precede clinical manifestations, and consequently ileocolonoscopy with histologic examination remains the gold standard in the evaluation of postsurgical recurrence [3]. It is suggested that postoperative management should include a colonoscopy 6-12 months after surgery to identify early recurrence [4].

Inflammatory parameters such as fecal calprotectin (FC) and lactoferrin have been thoroughly studied as noninvasive markers of gut inflammation and may play a role in predicting recurrence after surgery $[5,6]$. It has been proposed that FC should be measured 2 or 3 months after surgical resection. Both 200 and $300 \mu \mathrm{g} / \mathrm{g}$ as cut-offs have been proposed as predictors of endoscopic recurrence, with $63-78 \%$ sensitivity and $73-75 \%$ specificity [7-10]. Patients above this cut-off should be proposed for endoscopic evaluation [11].

Cross-sectional imaging by ultrasound, computed tomography (CT), or magnetic resonance imaging (MRI) provides additional information such as transmural involvement or extraintestinal manifestations. While endoscopy is invasive and bothersome, CT raises concerns about radiation exposure and MRI is expensive and not widely available. Ultrasound is an innocuous and ubiquitously available imaging method. Intestinal ultrasound (IUS) is relatively cheap, simple to perform, and easily accepted by patients. 
IUS includes standard abdominal ultrasound using a low-frequency convex probe (1-6 MHz) to identify bowel segments possibly involved. After this, for a more detailed evaluation a high-frequency linear probe (5-17 $\mathrm{MHz}$ ) is used [12]. Increased bowel wall thickness (WT) and high vascularization are considered the most prominent and sensitive signs of illness. Other parameters suggesting active $\mathrm{CD}$ include loss of wall stratification or loss of the 5-layer wall pattern, reduced compressibility, or stiffness of a bowel segment, fibrofatty proliferation, occurrence of extraintestinal structures such as mesenteric lymphadenopathy or entero-enteric free fluid, and even illness complications such as fistulae, strictures, or abscesses [13].

IUS has shown promising results in detecting endoscopic recurrence and determining its severity. The sensitivity and specificity of IUS in the diagnosis of postoperative recurrence have been described to be around 7994 and $86-100 \%$, respectively $[14,15]$.

Monitoring the activity of CD after surgery (ACD-AS) is a clinical challenge. Early and reliable identification of patients at risk of recurrence may allow its prevention. Even though endoscopy remains the exam of choice for the evaluation of ACD-AS, less invasive tests, alone or in combination, would be more cost-effective and accepted by the patient. IUS may represent a simple, accessible, and accurate noninvasive alternative.

We aim to determine the diagnostic accuracy and concordance of this modality compared to endoscopy, clinical manifestations, and inflammatory parameters in the Portuguese population of a tertiary referral center with expertise in IBD.

\section{Materials and Methods}

This is a cross-sectional study in a Portuguese tertiary referral center with expertise in IBD. We included, consecutively between December 2016 and February 2018, 39 patients with established $\mathrm{CD}$ and ileocecal resection due to IBD who were proposed to undergo an ileocolonoscopy by the assistant gastroenterologist. The exclusion criteria included: pregnancy, age younger than 18 years, and postoperative follow-up of less than 1 year.

IUS (HI-VISION Avius ${ }^{\circledR}$, Tokyo, Japan) was performed using a linear probe B-mode/Doppler prior to ileocolonoscopy. IUS and ileocolonoscopy were performed on the same day by 2 expert operators (specialists in Gastroenterology and dedicated to abdominal ultrasound and IBD) in a double-blind mode.

Demographic data and clinical activity were collected. Clinical activity was established by the Harvey-Bradshaw Index (HBI), considering remission if it was $\leq 4$ and activity if it was $\geq 5$ (mild, 5-7; moderate, 8-16; and severe $>16$ ). The following serological and fecal inflammatory parameters were included: leukocytes (4-
$10 \times 10^{9}$ cells/L), C-reactive protein (CPR; $\left.\leq 0.5 \mathrm{mg} / \mathrm{dL}\right), \mathrm{FC}(<50$ $\mathrm{mg} / \mathrm{kg}$ ), and other laboratorial data such as hemoglobin, mean corpuscular volume, and platelets. The most recent parameters obtained, before the day of the IUS and colonoscopy, were considered. In case of no recent analyses, blood and fecal samples were collected on the day of the ultrasonographic and endoscopic examination. Other clinical data collected included CD complications such as strictures, fistulae, and abscesses, as well as CD subtype as established by the Montreal classification, year of diagnosis and duration of $\mathrm{CD}$, medication, and date of surgery.

Three parameters to evaluate the ultrasonographic activity in the ileocolic anastomosis were acquired. First, the maximal intestinal wall thickening was measured, considering the mean value of 3 measurements from the most thickened ileocolic segment, as obtained in a cross-sectional view, from the hyperechogenic line corresponding to the center of the lumen to the serosa's hyperechogenic margin. We considered values $\leq 4 \mathrm{~mm}$ for the colon wall and $\leq 3 \mathrm{~mm}$ for the ileal wall as normal. Second, the pattern of the intestinal wall was determined as partial or total loss of stratification. Third, the digestive wall's vascularization was assessed using the power Doppler mode and an adaptation of the semiquantitative Limberg score (absent $=0$, sparse $=1$, moderate $=2$, and marked $=3$ ). The ultrasonographic severity was determined according to intestinal wall's thickening and vascularization and reported as a scale ranging from 0 to 3 . A score of 0 was attributed if the intestinal wall thickness was considered normal and no vascularization was reported. Scores from 1 to 3 included the presence of vascularization (adapted Limberg score $\geq 1$ ). Additionally, a score of 1 was considered if the WT was between 4 and $6 \mathrm{~mm}$, a score of 2 was used if the WT was between 6 and $8 \mathrm{~mm}$, and a score of 3 was used if the WT was greater than $8 \mathrm{~mm}$.

Endoscopic activity was assessed using the Rutgeerts score, with remission established as a score $<\mathrm{i} 2$ and postsurgical recurrence as a score $\geq \mathrm{i} 2$.

\section{Statistical Analysis}

Categorical data is presented as absolute frequencies and relative frequencies in percentages. Numerical data is presented as means $( \pm \mathrm{SD})$ or medians (IQR) according to the histogram distribution. Categorical variables were compared using the Pearson $\chi^{2}$ test or the Fisher exact test. To compare the different parameters in terms of their ability to identify subjects with postsurgical endoscopic recurrence, the areas under the receiver operating characteristic curve (AUROC) were obtained, considering a 95\% CI. The $\kappa$ coefficient was determined to compare endoscopic and ultrasonographic interobserver evaluations. Data was recorded, described, and analyzed using Statistical Package for the Social Sciences (SPSS) version 26 (SPSS Inc., Chicago, IL, USA). $p<0.05$ was considered statistically significant.

\section{Results}

We included 39 patients, described in Table 1. Twentyfive patients were female (64.1\%) and the mean age at the time of this study was $43.5 \pm 15.3$ years. Surgery was performed a median of 4 years (IQR 7) after the diagnosis and the median post-surgery follow-up was 9 years (IQR 9). 
Table 1. Main demographic and clinical characteristics of the 39 patients

\begin{tabular}{|c|c|}
\hline Variable & Value \\
\hline Females & $25(64.1)$ \\
\hline $\begin{array}{l}\text { Age at the beginning of this study, years } \\
\text { Age at diagnosis, years } \\
\text { Age at surgery, years }\end{array}$ & $\begin{array}{l}43.5 \pm 15.3 \\
29.3 \pm 13.7 \\
34.2 \pm 13.8\end{array}$ \\
\hline $\begin{array}{l}\text { Time from diagnosis until surgery, years } \\
\text { Postsurgery follow-up, years }\end{array}$ & $\begin{array}{l}4(1-8) \\
9(3-12)\end{array}$ \\
\hline $\begin{array}{l}\text { Illness location before surgery } \\
\text { Terminal ileum } \\
\text { Ileocolon }\end{array}$ & $\begin{array}{l}24(61.5) \\
15(38.5)\end{array}$ \\
\hline $\begin{array}{l}\text { Illness behavior before surgery } \\
\text { Nonstricturing and nonpenetrating } \\
\text { Stricturing } \\
\text { Penetrating }\end{array}$ & $\begin{array}{l}11(28.2) \\
11(28.2) \\
17(43.6)\end{array}$ \\
\hline Perianal disease & 7 (17.9) \\
\hline $\begin{array}{l}H B I \\
\text { Remission } \\
\text { Mild activity } \\
\text { Moderate activity }\end{array}$ & $\begin{array}{l}34(87.2) \\
3(7.7) \\
2(5.1)\end{array}$ \\
\hline $\begin{array}{l}\text { Laboratory findings } \\
\text { Hemoglobin, } \mathrm{g} / \mathrm{dL} \\
\text { MCV, } \mathrm{fL} \\
\text { Platelets, } n \times 10^{9} / \mathrm{L}\end{array}$ & $\begin{array}{l}13.8 \pm 1.2 \\
85.8 \pm 14.8 \\
254 \pm 82.7\end{array}$ \\
\hline $\begin{array}{l}\text { Inflammatory markers } \\
\text { Leukocyte count, } n \times 10^{9} / \mathrm{L} \\
\text { C-reactive protein, } \mathrm{mg} / \mathrm{dL} \\
\text { Fecal calprotectin, } \mathrm{mg} / \mathrm{kg}\end{array}$ & $\begin{array}{r}6.5 \pm 2.4 \\
0.3(0.1-0.9) \\
47.7(17-278)\end{array}$ \\
\hline $\begin{array}{l}\text { IBD complications before surgery } \\
\text { Stricture } \\
\text { Fistulae } \\
\text { Abscess } \\
\text { Neoplasia }\end{array}$ & $\begin{aligned} 17 & (43.6) \\
14 & (35.9) \\
6 & (15.4) \\
1 & (2.6)\end{aligned}$ \\
\hline
\end{tabular}

Values are presented as means $\pm \mathrm{SD}$, median (IQR), or numbers (\%). MCV, mean corpuscular volume.

The Montreal classification was as follows: L1, 61.5\% ( $n=$ $24)$; L3, 38.5\% ( $n=15) ; \mathrm{B} 1$ and $\mathrm{B} 2,28.2 \%(n=11)$; and $\mathrm{B} 3$, $43.6 \%(n=17)$. At the time of this study, 34 patients were in clinical remission $(87.2 \%)$, with a mean HBI of $2.1 \pm 2.2$. The leukocyte count was normal in 30 patients, the CRP level was normal in 25 patients, and the FC level was normal in 9 patients. Seventeen patients had an intestinal stenosis before entering the study, and 14 had a fistula, 6 had an abscess, and 1 had an adenocarcinoma of the colon. Overall, 9 patients $(23.1 \%)$ had more than 1 of the previously described IBD complications. Ten (25.6\%) had no IBD complications before entering this study.

Role of IUS in CD's Postsurgical Recurrence
From diagnosis until the surgery, 9 patients were under no treatment $(23.1 \%)$. Overall, 19 patients $(48.7 \%)$ were exposed to corticotherapy or other immunosuppressing therapies before surgery. Five patients were under treatment with tumor necrosis factor (TNF) inhibitor (12.8\%).

At the time of this study, 9 patients were not medicated $(23.1 \%)$ and 21 were under monotherapy, mostly with azathioprine (AZA). After surgery, 25 (64.1\%) patients were exposed to AZA and 9 were exposed to anti-TNF (23.1\%; infliximab in 5 patients and adalimumab in 4 patients). Overall, $76.9 \%$ of the patients were medicated with immunomodulators or immunosuppressants after 
Table 2. Ultrasonographic findings in the 39 IUS

\begin{tabular}{lc}
\hline Variable & Value \\
\hline WT, mm & $4.55 \pm 1.95$ \\
\hline DW vascularization & $21(53.8)$ \\
0 & $10(25.6)$ \\
1 & $5(12.8)$ \\
2 & $3(7.7)$ \\
3 & $8(20.5)$ \\
\hline DW loss of stratification & $18(46.2)$ \\
\hline Sonographic severity & $12(30.8)$ \\
0 & $6(15.4)$ \\
1 & $2(5.1)$ \\
3
\end{tabular}

Values are presented as means \pm SD or numbers (\%).

surgery. Exposures to immunosuppressors, with corticotherapy excluded, before and after surgery ( 5 vs. 9 ) were comparable $(p=0.587)$.

\section{Ultrasonographic and Endoscopic Findings}

IUS and ileocolonoscopy were performed in each patient on the same day. IUS was abnormal in $61.5 \%(n=$ 24 ) of the patients, as defined by the presence of intestinal wall thickening $>3 \mathrm{~mm}$ and/or a Limberg score $>1$. Further ultrasonographic findings are described in Table 2.

Twenty-one patients were in endoscopic remission (Rutgeerts score $<\mathrm{i} 2 ; 53.8 \%)$. Among the 18 (46.2\%) patients with endoscopic recurrence, the endoscopy Rutgeerts scores were: i2 in $5(12.8 \%)$, i3 in $4(10.3 \%)$, and i4 in $9(23.1 \%)$ patients. We found a statistically significant association between ultrasonographic severity and endoscopic severity, as established by a higher Rutgeerts score ( $p=0.005$ ). Overall, 18 patients had endoscopic postoperative recurrence and 24 had abnormal IUS findings. Only 1 patient of the 8 , with a WT $>6 \mathrm{~mm}$ and hypervascularization, did not show endoscopic recurrence, with a Rutgeerts score of il. Table 3 shows the measures of central tendency of the inflammatory serological and fecal parameters and ultrasonographic findings when comparing patients with and without endoscopic recurrence.

\section{Clinical Findings and Ultrasonographic Severity and}

Endoscopic Recurrence

When comparing gender with altered IUS and endoscopic recurrence, we did not find a significant difference
(52\% of the women and $78.6 \%$ of the men had an altered IUS [ $p=0.102]$, and $36 \%$ of the women and $64.3 \%$ of the men had endoscopic recurrence [ $p=0.089])$. The age at IBD onset, as defined by the Montreal classification, was not significantly associated with an altered IUS $(p=0.534)$ or endoscopic recurrence ( $p=0.085)$. Disease location was not associated with an altered IUS or endoscopic recurrence ( $p=0.876$ and $p=0.543$, respectively). Disease behavior was also not associated with an altered IUS or endoscopic recurrence ( $p=0.264$ and $p=0.69$, respectively). Absence of perianal disease was more frequent in patients with no sign of severity in the IUS (15 of the 18 patients with no severity signs) but this difference was not statistically significant $(p=0.15)$.

Elevated serological inflammatory parameters (leukocyte count and CRP) compared to abnormal findings in ultrasonography and endoscopic recurrence showed a significant association ( $82.4 \%$ had both altered IUS and inflammatory parameters and $54.5 \%$ had normal findings [ $p=0.019]$, and $64.7 \%$ had abnormal inflammatory parameters and endoscopic recurrence and $68.2 \%$ had normal findings $[p=0.041])$. However, having altered inflammatory laboratorial parameters was not significantly more frequent in patients who met the ultrasonographic criteria for severity (a score of 1 for $29.4 \%$ of the patients with altered inflammatory parameters vs. $31.8 \%$ of the patients with normal laboratory findings, a score of 2 for 23.5 vs $9.1 \%$ of the patients, and a score of 3 for 11.8 vs. $0 \%$ of the patients; $p=0.112$ ).

Clinical activity was more frequent in men ( $4 \%$ of the women had active disease vs. $28.6 \%$ of the men; $p=0.047$ ) and it was associated with altered inflammatory parameters $(p=0.011)$. All patients with clinically active IBD had an altered IUS, although this difference was not statistically significant $(p=0.136)$. Loss of wall stratification was more common in symptomatic patients $(37.5 \%$ of patients with DW loss of stratification had active disease and $93 \%$ with no loss of stratification were in clinical remission; $p=0.049$ ) and no patients with clinically active IBD presented a Limberg score of $0(p=0.009)$. Severity as determined by the IUS was significantly associated with an HBI above $4(p<0.001)$. Clinical activity was also significantly associated with endoscopic recurrence ( $p=$ $0.015)$.

\section{Clinical and Inflammatory Parameters for Prediction} of Endoscopic Recurrence

Age, gender, the Montreal classification, and immunosuppression before and after surgery did not show a good performance in predicting endoscopic recurrence, 
Table 3. Comparison of clinical parameters, ultrasonographic findings, and inflammatory parameters with an absence or presence of endoscopic recurrence, as defined by a Rutgeerts score $\geq \mathrm{i} 2$

\begin{tabular}{|c|c|c|c|}
\hline & $\begin{array}{l}\text { Absence of endoscopic } \\
\text { recurrence } \\
\text { (Rutgeerts' score i0 or i1) } \\
(n=21)\end{array}$ & $\begin{array}{l}\text { Presence of endoscopic } \\
\text { recurrence } \\
\text { (Rutgeerts' score } \geq \mathrm{i} 2) \\
(n=18)\end{array}$ & $p$ value \\
\hline \multicolumn{4}{|l|}{ Clinical parameters } \\
\hline Females & 16 & 9 & 0.108 \\
\hline Age, years & $41.3 \pm 14.4$ & $46.2 \pm 16.3$ & 0.328 \\
\hline Remission & 21 & 13 & \\
\hline Mild activity & 0 & 3 & \\
\hline Moderate activity & 0 & 2 & \\
\hline \multicolumn{4}{|l|}{ Ultrasonographic findings } \\
\hline Abnormal ultrasound & 8 & 16 & 0.002 \\
\hline Presence of vascularization & 3 & 15 & $<0.001$ \\
\hline $\mathrm{FC}, \mathrm{mg} / \mathrm{kg}$ (range) & $47.7(13-600)$ & $224(11-700)$ & 0.477 \\
\hline CRP, mg/dL (range) & $0.2(0.03-2)$ & $0.4(0.1-14)$ & 0.149 \\
\hline Leukocyte count, $n \times 10^{9} / \mathrm{L}$ & $6,171 \pm 1,849$ & $6,975 \pm 2,979$ & 0.32 \\
\hline
\end{tabular}

while the presence of IBD complications seemed to show a tendency toward a reasonable diagnostic accuracy; although this was not statistically significant (AUROC = 0.68 ; $95 \%$ CI $0.49-0.86, p=0.063$ ), it was higher than HBI.

None of the laboratory parameters reached statistical significance in predicting endoscopic recurrence, with FC, leukocyte count, and platelets sharing an AUROC of 0.61 (95\% CI $0.21-1, p=0.514$; 95\% CI 0.42-0.8, $p=$ 0.257 ; and 95\% CI 0.24-0.99, $p=0.191$, respectively). Platelets levels $\geq 301.5 \times 10^{9} / \mathrm{L}$ and FC $\geq 377 \mathrm{mg} / \mathrm{kg}$ showed $50 \%$ sensitivity and $91 \%$ specificity for diagnosing endoscopic recurrence.

\section{Ultrasonography for Assessment of Endoscopic}

\section{Recurrence}

Compared to endoscopy, ultrasonography showed a moderate concordance with endoscopic findings $(\mathrm{K}=0.5$, $p=0.001)$, which is higher than that for inflammatory parameters $(\mathrm{K}=0.33, p=0.041)$ and clinical manifestations $(\mathrm{k}=0.29, p=0.01)$. Abnormal ultrasonography predicted endoscopic recurrence with $88.9 \%$ sensitivity and $61.9 \%$ specificity. The positive predictive value was $66.7 \%$ and the negative predictive value was $86.7 \%$.

Role of IUS in CD's Postsurgical Recurrence
Compared to the gold-standard, i.e., endoscopy, severity on IUS (AUROC $=0.82$; 95\% CI $0.69-0.96, p=0.001$ ) and altered IUS (AUROC $=0.75,95 \%$ CI 0.6-0.91, $p=$ 0.007 ) showed a good diagnostic accuracy. Serological inflammatory parameters (AUROC $=0.66$; 95\% CI $0.49-$ $0.84, p=0.083$ ) and clinical manifestations (AUROC $=$ 0.64 ; $95 \%$ CI $0.46-0.82, p=0.139$ ) did not predict endoscopic recurrence, as shown in Figure 1. A model considering altered FC (above the superior limit of normalcy) plus altered IUS did not increase the accuracy for predicting endoscopic recurrence with an AUROC of 0.633 ( $p=$ $0.551 ; 95 \%$ CI $0.213-1$ ).

When comparing ultrasonographic variables and laboratorial findings on their accuracy for endoscopic recurrence diagnosis, digestive loss of wall stratification and vascularization showed superiority $(\mathrm{AUROC}=0.875$; $95 \%$ CI $0.61-1, p=0.031$, and AUROC $=0.852 ; 95 \%$ CI $0.58-1, p=0.043$, respectively). When it comes to WT, it showed superiority compared to laboratory findings but both loss of wall stratification and vascularization had a better performance (AUROC $=0.796$; 95\% CI 0.651$0.942, p=0.002$ ), as shown in Figure 2. A WT $\geq 3.9 \mathrm{~mm}$ showed $88.9 \%$ sensitivity and $71.4 \%$ specificity for diagnosing endoscopic recurrence. 


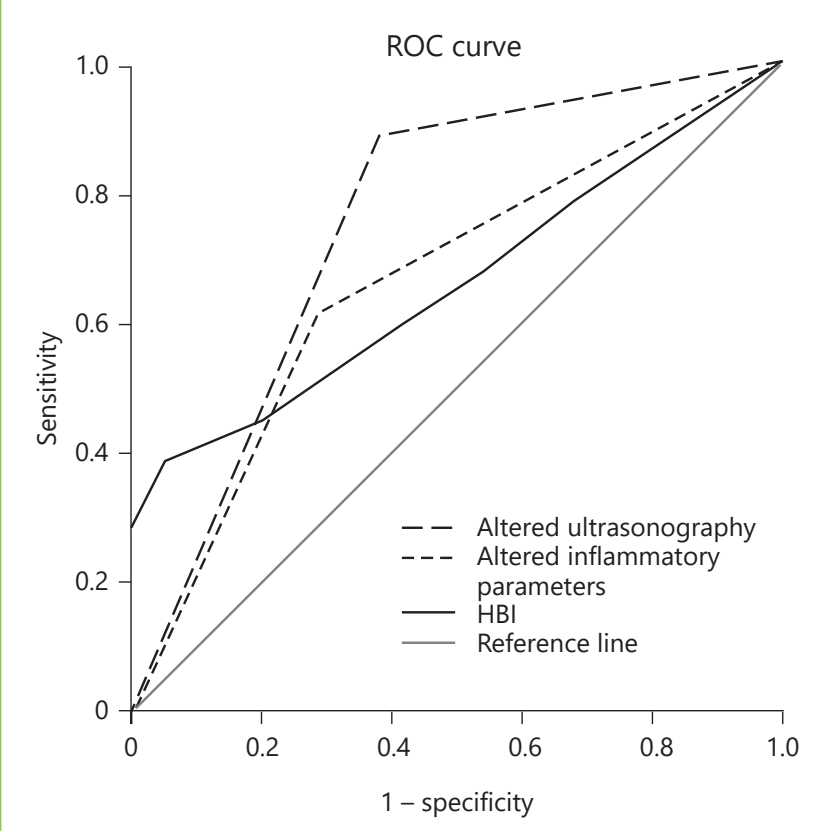

Fig. 1. Comparison of the performance of altered ultrasonography, altered inflammatory parameters, and HBI in diagnosing endoscopic recurrence.

\section{Discussion/Conclusion}

The European Crohn's and Colitis Organization (ECCO) guidelines have recognized ultrassonography as a promising emerging tool and a noninvasive alternative to ileocolonoscopy for identification of postsurgical recurrence [16]. Ileocolonoscopy maintains its essential role in postsurgical CD follow-up. Endoscopic recurrence correlates with the development of clinical recurrence and subsequently with the development of complications and the need for reintervention. However, its invasiveness, the need for bowel preparation, and the greater difficulty in performing it in patients who have undergone surgery led to a substantial interest in IUS. Several studies have demonstrated that IUS is an adequate imaging exam for identifying IBD activity, but there are only a few studies on its application in recurrence of postsurgical $\mathrm{CD}$, which is the purpose of our study. Additionally, there are concerns regarding whether mural healing changes evaluated by cross-sectional imaging exams occur in parallel to the endoscopic mucosal alterations, as evaluated by the Rutgeerts score [12].

Most studies have indicated that gender and age at diagnosis do not have an impact on the recurrence rate of postsurgery $\mathrm{CD}$, as found in our cohort [1]. Although

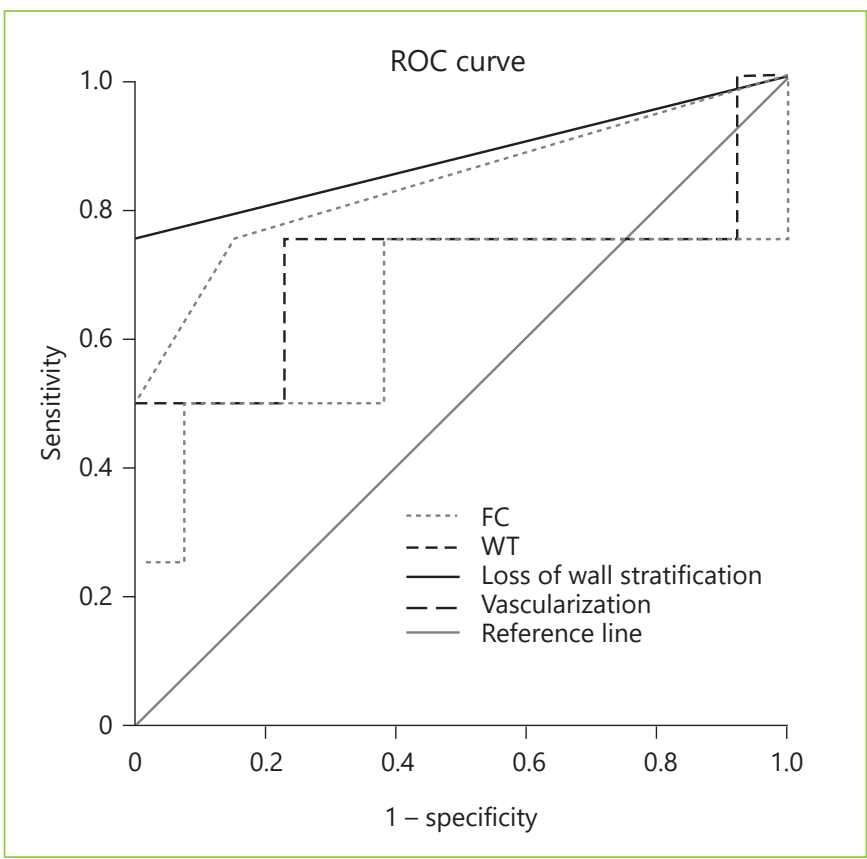

Fig. 2. Comparison of the performance of FC, WT, loss of wall stratification, and vascularization in diagnosing endoscopic recurrence.

smoking is a widely recognized risk factor for CD recurrence, this factor was not evaluated in this study [17]. Disease location or behavior did not confer a higher rate of endoscopic recurrence.

In our series, ultrasound revealed overall results similar to those described in the literature, with $75 \%$ accuracy for diagnosis of endoscopic recurrence and particularly high sensitivity and negative predictive values ( 89 and $87 \%$, respectively) $[15,18-20]$. This suggests that, if normal, an IUS could postpone or avoid ileocolonoscopy. If ultrasonographic findings suggest severe IBD activity, its accuracy for diagnosing endoscopic recurrence is even higher (i.e., $82 \%)$. IUS will be limited in the first months following resection, as mentioned by Rispo et al. [14]. Severe abnormalities found in IUS related to disease activity may be absent in an evaluation this early. To avoid underestimation of IUS accuracy, we excluded patients who had undergone surgery in the previous year. This could, however, imply that ultrasonographic evaluation could only avoid or postpone ilecolonoscopy several months after surgery and the role of early IUS should be further investigated.

In our study, the best ultrasonographic parameter for the diagnosis of postsurgical endoscopic recurrence was loss of wall stratification and, secondly, vascularization. Wall stratification is usually discarded as less sensitive, as 
it is not as objective as WT, but a few studies have shown its relevance in reliable assessment of illness activity [21, 22]. Additionally, its normalization after biological therapy has been reported [23]. Given our results, the addition of loss of wall stratification to future scores should be considered. Regarding hypervascularization, it has been less investigated and always taken into consideration in association with other findings such as WT. Currently there is no objective scale to determine the degree of disease activity on Doppler US, and information on its value despite WT in postsurgical recurrence is lacking.

WT is the most studied and the cut-off value for considering the intestinal wall as thickened has long been a matter of discussion. We chose $>3 \mathrm{~mm}$ as indicative of pathology for the ileum as it is the most uniform consensus. Nevertheless, when using the ROC curve to determine the cut-off better fitted to diagnose endoscopic recurrence, a WT $\geq 3.9 \mathrm{~mm}$ had the best performance. A WT $>7 \mathrm{~mm}$ has been described as associated with a significant risk of intestinal resection over a short period of time, and a WT $>5 \mathrm{~mm}$ is strongly indicative of severe endoscopic postsurgical recurrence [14, 22]. Cammarota et al. [17] showed that a WT $>3 \mathrm{~mm}$ implied a doubled risk of postsurgical recurrence compared to a WT $<3 \mathrm{~mm}$. Many cut-off points have been proposed, and standardization is lacking. Still, a higher WT is consistently described as increasing the risk of postsurgical recurrence.

One of the main limitations of the study is its design. A longitudinal study, with clinical, endoscopic, and ultrasonographic follow-up, would allow us to evaluate in more detail the development of recurrence, its severity, and its timing. All examinations were performed with the same US equipment, which may limit this study's external validity, but, on the other hand, reduces the variability inherent to different technical equipment. Another limitation is our small sample size, which could limit our statistical power. One of the major advantages of this study is its use of a focused digestive wall ultrasound performed by 2 experts in the area, limiting the subjectiveness error inherent to ultrasonographic evaluation. Moreover, in future studies, a blind third expert reviewing the ultrasonographic findings could be considered to further limit the subjectiveness.

Contrast-enhanced US and elastography have been described to improve the diagnostic accuracy for detection of IBD activity and testing this hypothesis in our population should be our next step. For use in future clinical practice, the development of a noninvasive score including ultrasonographic findings, clinical parameters, and biomarkers such as FC could be useful to identify more accurately patients at a higher risk of recurrence and avoid standard and undifferentiated use of ileocolonoscopy. FC $\geq 377 \mathrm{mg} / \mathrm{kg}$ had the best performance in our cohort, with $91 \%$ specificity and only $50 \%$ sensitivity (surprisingly the same as for platelets $\geq 301.5 \times 10^{9} / \mathrm{L}$ ). The previously described FC cut-off value for prediction of endoscopic recurrence was $>200 \mathrm{mg} / \mathrm{kg}$, with $63 \%$ sensitivity and $75 \%$ specificity [23]. A simple model considering altered FC and altered IUS did not obtain the expected results with an AUROC of 0.633 , so redefining the cut-off point for altered FC or the timing of fecal sampling obtention should be considered. A detailed examination should be taken to obtain an adequate combined model.

In conclusion, the ultrasonographic evaluation of the digestive wall showed 75\% diagnostic accuracy and moderate agreement with endoscopic recurrence in postsurgical CD patients. Ultrasonographic parameters, particularly loss of wall stratification and vascularization, showed significant superiority when compared to clinical and inflammatory parameters. So, IUS seems to be a useful tool for prediction of postsurgical recurrence in IBD. Overall, our findings suggest that a normal IUS could postpone or avoid ileocolonoscopy.

\section{Statement of Ethics}

Written informed consent was provided by the patients. The study protocol was approved by the institute's committee on human research.

\section{Conflict of Interest Statement}

The authors declare no conflict of interests.

Funding Sources

None.

\section{Author Contributions}

Cláudia Patricia Macedo was responsible for data acquisition and editing, the writing of this paper, and review of the literature. Mara Sarmento Costa was responsible for the writing of this paper and review of the literature. Cláudia Patricia Macedo and Mara Sarmento Costa contributed equally and are considered cofirst authors. Elisa Gravito-Soares and Marta Gravito-Soares designed the concept and plan of this study and were responsible for data acquisition and review of this paper. Ana Margarida Ferreira and Francisco Portela were responsible for data acquisition and review of this paper. Pedro Figueiredo reviewed this work. All the authors agreed with the final version of this work. 


\section{References}

1 Bernell O, Lapidus A, Hellers G. Risk factors for surgery and postoperative recurrence in Crohn's disease. Ann Surg. 2000 Jan; 231(1):38-45.

2 Rutgeerts P, Geboes K, Vantrappen G, Beyls J, Kerremans R, Hiele M. Predictability of the postoperative course of Crohn's disease. Gastroenterology. 1990 Oct;99(4):956-63.

3 Paredes JM, Ripollés T, Cortés X, Moreno N, Martínez MJ, Bustamante-Balén $M$, et al. Contrast-enhanced ultrasonography: usefulness in the assessment of postoperative recurrence of Crohn's disease. J Crohn's Colitis. 2013 Apr;7(3):192-201.

4 Regueiro M. Management and prevention of postoperative Crohn's disease. Inflamm Bowel Dis. 2009 Oct;15(10):1583-90.

5 Scarpa M, D'Incà R, Basso D, Ruffolo C, Polese L, Bertin E, et al. Fecal lactoferrin and calprotectin after ileocolonic resection for Crohn's disease. Dis Colon Rectum. 2007 Jun;50(6):861-9.

6 Sorrentino D, Paviotti A, Terrosu G, Avellini C, Geraci M, Zarifi D. Low-dose maintenance therapy with infliximab prevents postsurgical recurrence of Crohn's disease. Clin Gastroenterol Hepatol. 2010 Jul;8(7):591-9.e1.

7 Lamb CA, Mohiuddin MK, Gicquel J, Neely D, Bergin FG, Hanson JM, et al. Faecal calprotectin or lactoferrin can identify postoperative recurrence in Crohn's disease. Br J Surg. 2009 Jun;96(6):663-74.

8 Orlando A, Modesto I, Castiglione F, Scala L, Scimeca D, Rispo A, et al. The role of calprotectin in predicting endoscopic post-surgical recurrence in asymptomatic Crohn's disease: a comparison with ultrasound. Eur Rev Med Pharmacol Sci. 2006 Jan-Feb;10(1):17-22.

9 Lobatón T, López-García A, Rodríguez-Moranta F, Ruiz A, Rodríguez L, Guardiola J. A new rapid test for fecal calprotectin predicts endoscopic remission and postoperative recurrence in Crohn's disease. J Crohn's Colitis. 2013 Dec;7(12):e641-51.
10 Louis E, Mary JY, Vernier-Massouille G, Grimaud JC, Bouhnik Y, Laharie D, et al.; Groupe D'etudes Thérapeutiques Des Affections Inflammatoires Digestives. Maintenance of remission among patients with Crohn's disease on antimetabolite therapy after infliximab therapy is stopped. Gastroenterology. 2012 Jan;142(1):63-70.e5.

11 Mao R, Xiao YL, Gao X, Chen BL, He Y, Yang $\mathrm{L}$, et al. Fecal calprotectin in predicting relapse of inflammatory bowel diseases: a metaanalysis of prospective studies. Inflamm Bowel Dis. 2012 Oct;18(10):1894-9.

12 Papay P, Ignjatovic A, Karmiris K, Amarante $\mathrm{H}$, Milheller P, Feagan B, et al. Optimising monitoring in the management of Crohn's disease: a physician's perspective. J Crohn's Colitis. 2013 Sep;7(8):653-69.

13 Connelly TM, Messaris E. Predictors of recurrence of Crohn's disease after ileocolectomy: a review. World J Gastroenterol. 2014 Oct;20(39):14393-406.

14 Schoepfer AM, Trummler M, Seeholzer P, Seibold-Schmid B, Seibold F. Discriminating IBD from IBS: comparison of the test performance of fecal markers, blood leukocytes, $\mathrm{CRP}$, and IBD antibodies. Inflamm Bowel Dis. 2008 Jan;14(1):32-9.

15 Panes J, Bouhnik Y, Reinisch W, Stoker J, Taylor SA, Baumgart DC, et al. Imaging techniques for assessment of inflammatory bowel disease: joint ECCO and ESGAR evidencebased consensus guidelines. J Crohn's Colitis. 2013 Aug;7(7):556-85

16 Kucharzik T, Maaser C. Intestinal ultrasound and management of small bowel Crohn's disease. Therap Adv Gastroenterol. 2018. doi: $10.1177 / 1756284818771367$.

17 Rispo A, Bucci L, Pesce G, Sabbatini F, de Palma GD, Grassia R, et al. Bowel sonography for the diagnosis and grading of postsurgical recurrence of Crohn's disease. Inflamm Bowel Dis. 2006 Jun;12(6):486-90.

18 Andreoli A, Cerro P, Falasco G, Giglio LA, Prantera C. Role of ultrasonography in the diagnosis of postsurgical recurrence of Crohn's disease. Am J Gastroenterol. 1998 Jul; 93(7):1117-21.
19 Maaser C, Sturm A, Vavricka SR, Kucharzik T, Fiorino G, Annese V, et al.; European Crohn's and Colitis Organisation [ECCO] and the European Society of Gastrointestinal and Abdominal Radiology [ESGAR]. ECCOESGAR Guideline for Diagnostic Assessment in IBD Part 1: initial diagnosis, monitoring of known IBD, detection of complications. J Crohn's Colitis. 2019 Feb;13(2):144-64.

20 Cammarota T, Ribaldone DG, Resegotti A, Repici A, Danese S, Fiorino G, et al. Role of bowel ultrasound as a predictor of surgical recurrence of Crohn's disease. Scand J Gastroenterol. 2013 May;48(5):552-5.

21 Kucharzik T, Kannengiesser K, Petersen F. The use of ultrasound in inflammatory bowel disease. Ann Gastroenterol. 2017;30(2):13544.

22 Biancone L, Onali S, Calabrese E, Petruzziello C, Zorzi F, Condino G, et al. Non-invasive techniques for assessing postoperative recurrence in Crohn's disease. Dig Liver Dis. 2008 Jul;40 Suppl 2:S265-70.

23 Greenup AJ, Bressler B, Rosenfeld G. Medical Imaging in Small Bowel Crohn's DiseaseComputer Tomography Enterography, Magnetic Resonance Enterography, and Ultrasound: "Which One Is the Best for What?". Inflamm Bowel Dis. 2016 May;22(5):124661.

24 Conti CB, Giunta M, Gridavilla D, Conte D, Fraquelli M. Role of Bowel Ultrasound in the Diagnosis and Follow-up of Patients with Crohn's Disease. Ultrasound Med Biol. 2017 Apr;43(4):725-34.

25 Castiglione F, de Sio I, Cozzolino A, Rispo A, Manguso F, Del Vecchio Blanco G, et al. Bowel wall thickness at abdominal ultrasound and the one-year-risk of surgery in patients with Crohn's disease. Am J Gastroenterol. 2004 Oct;99(10):1977-83.

26 Ercole E, Rigazio C. Role of bowel ultrasound in the management of postoperative Crohn's disease. World J Gastrointest Pathophysiol. 2014 Nov;5(4):457-61. 